\title{
Impact of Cropping Pattern of Catchment Area on Water Quality Characteristics of Riverine Ecosystem
}

\author{
Kusumlata Goswami*, Mahima Tamta, Sumit Kumar and R. N. Ram \\ Department of Fisheries Resource Management, College of Fisheries, \\ GBPUA\&T, Pantnagar, Uttarakhand, India \\ *Corresponding author
}

\section{A B S T R A C T}

Keywords

Cropping pattern, Hydrologic system, Riverine ecosystem, Water quality

\section{Article Info}

Accepted: 04 September 2019 Available Online: 10 October 2019
Land use cropping pattern are altering the hydrologic system and have potentially large impacts on water resources. The present study aims at analyzing the impact of various cropping patterns on water quality parameters of rivers located at Pantnagar, for a duration of three months from August, 2017 to October, 2017. Three sites Barour $\left(S_{1}\right)$, Beni $\left(S_{2}\right)$ and Chakpheri $\left(\mathrm{S}_{3}\right)$ were selected which exhibits different cropping pattern in their catchment area i. e. Paddy (Oryza sativa), Dhaincha (Sesbania bispinosa) and Maize (Zea mays) respectively. Study concludes that variation in cropping pattern exhibits changes in the water quality parameters of their respective riverine ecosystem. So, to manage our water quality parameters we should perform integrated management along with agriculture sector.

\section{Introduction}

Agriculture is the mainstay of many developing economies, contributing significantly to GDP, food security, direct employment, export earnings and raw materials for other sectors (Kutywawo et al., 2012). With the world's population continuing to rise, greater demands are being placed on our natural resources. The growing demand of population has resulted in an expansion of agriculture. There is a large probability that nutrients and sediment will be delivered to nearby surface waters from both urban and agricultural land. Krantz and Kifferstein (2005) have argued the importance of understanding water quality problems associated with land use effects, in order that we can be instrumental in helping solve these problems. This reinforces the notion of how critical it is to understand the effects of landbased developments on our rivers and lakes, in order to consider appropriate and sustainable management of these activities. 
Land use changes have potentially large impacts on water resources (Stonestrom et al., 2009). The relationship between land use and water quality is helpful for identifying primary threats to water quality, and the relationships are meaningful for effective water quality management because they can be used to target critical land use areas and to institute relevant measures to minimize pollutant loadings (Abler et al., 2002). Agricultural activity results in ground and surface water pollution from nitrogen and phosphorus compounds, which results from the excessive use of fertilizers containing these ingredients (Wolska et al., 2001). Water pollution occurs because human activities such as agriculture, forest harvest, and urbanization have altered the structure of the rural landscape and increased the quantity of substances like sediments, nitrogen, chlorine, etc. loaded to the river system (Anbumozhi et al., 2005).

The rapid expansion of agriculture over the past few centuries led to conversion of natural or native vegetation to cultivated agricultural systems. Such changes to land use and agricultural practices have significantly increased leaching of chemicals to surface and ground waters (Carpenter et al., 1998).

Several studies also reported a strong relationship between cropping pattern changes and nutrient level enhancements in watersheds (Liu et al., 2000).

Thus, water quality in agro-ecosystems has become an important environmental concern, which has resulted in an expansive body of literature investigating the relationships between agricultural land use/land cover and water quality. The present study was carried out to evaluate the impact of cropping pattern of catchment area on water quality characteristics of riverine ecosystem in three riverine ecosystems located at Pantnagar of Uttarakhand, India.

\section{Materials and Methods}

\section{Experimental Site}

The present study was carried out in three riverine ecosystems i.e., Barour $\left(\mathrm{S}_{1}\right)$, Beni $\left(\mathrm{S}_{2}\right)$ and Chakpheri $\left(\mathrm{S}_{3}\right)$ located in Pantnagar region, Udham Singh Nagar district of state Uttarakhand, India. Sampling of water was done from these three rivers located at Pantnagar, which were approximately 1-2 kms apart from each other. These rivers exhibit different cropping pattern in their catchment area as presented in Table 1.

\section{Duration of Experiment}

Experiment was performed for the duration of three months from August, 2017 to October, 2017. Weekly sampling of water and soil quality parameters was performed during the mentioned post monsoon period and observed for further analysis.

\section{Parameters observed}

Different water and soil quality parameters were observed to estimate the impact of cropping pattern of catchment area on physico-chemical characteristics of water quality.

\section{Soil analysis}

Assessment of soil quality of catchment area was done by estimating parameters like soil $\mathrm{pH}$, organic carbon, nitrate nitrogen and phosphate phosphorous. Soil samples were collected, air dried and sieved for analysis of various parameters.

\section{Water quality parameters}

Sampling for analysis of water parameters was performed during desired period. Water samples were taken in sampling bottles and 
then analyzed by following standardized methods of APHA, 2012. Physical parameters including water temperature and Total Dissolved Solids (TDS) and chemical parameters including water $\mathrm{pH}$, dissolved oxygen (DO), free carbon dioxide $\left(\mathrm{CO}_{2}\right)$ and total alkalinity were estimated from the water samples.

\section{Results and Discussion}

\section{Water Quality Parameters}

\section{Temperature}

It plays very important role in functioning of chemical and biological activities of organisms in the aquatic media (Bera et al., 2014). Riperian zone reduce water temperature by shadow effect, decrease sediment input, filter fertilizer and chemical substances and thus increase water quality (Gyawali et al., 2013; Mello et. al., 2017). It ranges from $25.2{ }^{\circ} \mathrm{C}$ in October to $30.8{ }^{\circ} \mathrm{C}$ in September. Due to monsoon season in August temperature was moderate. Maximum temperature was recorded in September but as winter approaches it starts decreasing from October. Out of these three rivers highest temperature was recorded in Beni river due to its less depth and blockage of river flow by artificial impoundment, whereas minimum temperature was observed in Chakpheri river due to its turbulent water flow conditions. Similar trend of decrease in temperature as winter approaches was observed in the water quality among different ghats of river Ganga at Kanpur, India (Khatoon et al., 2013) (Fig. 1).

\section{pH}

It is the measure of the acidity or alkalinity of a water body (Jadhav et al., 2013). It shows inverse relation with carbon dioxide content because $\mathrm{CO}_{2}$ increases the acidity of water body by formation of carbonic acid, therefore with increase in $\mathrm{CO}_{2}$ content $\mathrm{pH}$ of waterbody decreases. It also shows positive correlation with alkalinity of water body. Average $\mathrm{pH}$ value of all the three rivers is approximately same but its value increases as winter approaches due to increase in DO and decrease in $\mathrm{CO}_{2}$ content. Santhosh and Singh (2007) reported that suitable $\mathrm{pH}$ range is 6.7 to 9.5 for fish culture whereas above or below this level of $\mathrm{pH}$ is stressful to the fishes. The present value of $\mathrm{pH}$ is lies between the reported $\mathrm{pH}$ range which depicts that water condition is grossly suitable for fish and fisheries (Fig. 2 and Table 2).

\section{Total Dissolved Solids (TDS)}

Its value ranges from 245-319 mg/l. Similar findings have been reported by Thirupathaiah et al., 2012. TDS of August is high then September because of high influx of sediments in monsoon season and TDS value shoots up invariably in all the three rivers in October which may be due to reduction in growth of primary producers (phytoplanktons), which utilizes the dissolved solids of water and hence large amount of dissolved solids remain in waterbody. Out of these three rivers maximum dissolved solids are present in Beni river (Fig. 3).

\section{Dissolved Oxygen (DO)}

Dissolved oxygen content is indispensable for many aquatic organisms and it also affects the solubility and availability of many nutrients which has direct influence on primary productivity (Salahuddin et al., 2014). As winter approaches, temperature of waterbody decreases which causes increase in concentration of dissolved oxygen content of water body, so DO content increases from August to October in all the three water bodies. Among the three rivers maximum dissolved oxygen content was present in river 
Chakpheri due to its flow and turbulence. Kulkarni (2016) also concluded that water flow regime has a great impact on dissolved oxygen content of water body (Fig. 4).

\section{Free carbon dioxide $\left(\mathrm{CO}_{2}\right)$}

It varies inversely with dissolved oxygen concentration of water. So minimum concentration of free $\mathrm{CO}_{2}$ was found in winters i.e. in October.

Similar pattern of inverse correlation between dissolved oxygen and free $\mathrm{CO}_{2}$ was indicated by Nimgare et al., 2014. Free $\mathrm{CO}_{2}$ content of these three rivers varies from $0-2.4 \mathrm{mg} / \mathrm{l}$. Its value for Beni and Barour river was higher than Chakpheri due to their higher temperature and less DO content (Fig. 5).

\begin{abstract}
Alkalinity
It indicates the presence of carbonate and bicarbonate salts present in waterbody. It shows positive correlation with $\mathrm{pH}$ of water body means high alkalinity tends to increase the $\mathrm{pH}$ of waterbody (Fig. 6).
\end{abstract}

Total alkalinity in the lake followed increasing trend as winter approaches. Agarwal and Thapliyal (2005) also obtained maximum alkalinity during winter months in Bhilangana.

\section{Soil Quality Characteristics}

\section{Soil pH}

It is an important indicator of soil health, which affects crop yields, crop suitability, plant nutrient availability, and soil microorganism activity. It is determined largely by soil composition, cation exchange processes and hydrolysis reactions associated with the various organic and inorganic soil components (Narsimha et. al., 2013). It varies inversely with organic carbon content, when soil is more carbonic it has less $\mathrm{pH}$ than low carbon containing soil. Soil contains more $\mathrm{pH}$ during winter months because of less dissociation of organic matter due to relatively less microbial activity. The value of catchment area soil $\mathrm{pH}$ ranges from $7-7.8$ as indicated in Figure 7.

\section{Organic carbon content}

Organic carbon content of soil plays an important role as a source of plant nutrients and in maintaining the soil integrity (Solanki and Chavda, 2012). Out of the three catchment area soil, maximum organic carbon is present in the soil around Chakpheri river due to high rate of organic matter decomposition in relatively moist condition.

In August, catchment area around Chakpheri is barren containing more organic matter, whereas catchment area of Beni contains Paddy which utilizes more nutrients including organic carbon from soil, thus this soil contain less carbon content. The organic carbon content of soil ranges from $0.6-1.8 \%$ as presented in Figure 8, which is in accordance with Fomenky et al., (2018).

\section{Available Nitrogen}

Nitrogen is unique among major nutrient elements in that soil reserves are almost entirely in the organic form. Most of the nitrogen in the soil is organically bound. Available nitrogen is usually used to measure the basic fertility of soil and crop growth (Gao et al., 2018). Its value ranges from $125.4 \mathrm{~kg} / \mathrm{ha}$ to $288.5 \mathrm{~kg} / \mathrm{ha}$, which is represented in Figure 9.

\section{Available phosphorous}

Phosphorus is a major essential plant macro nutrient which is needed for plant growth and development (Koralage et al., 2015). Its primary role in a plant is to store and transfer 
energy produced by photosynthesis for use in $15 \%$ to $80 \%$ of the total phosphorous in soils growth and reproductive processes. Soil (Havlin et al., 2005). Phosphorus is lost from organic phosphorous generally accounts for crop lands via erosion or runoff.

Table.1 Variation of cropping pattern in the catchment area of different rivers

\begin{tabular}{|c|c|c|}
\hline Site & River & Crop of catchment area \\
\hline $\mathbf{S}_{\mathbf{1}}$ & Beni & Paddy (Oryza sativa) \\
\hline $\mathbf{S}_{\mathbf{2}}$ & Barour & Dhaincha (Sesbania bispinosa) \\
\hline $\mathbf{S}_{\mathbf{3}}$ & Chakpheri & Maize (Zea mays) \\
\hline
\end{tabular}

Table.2 Variations in water quality of rivers and soil quality of catchment area

\begin{tabular}{|c|c|c|c|c|c|c|c|c|c|c|}
\hline \multicolumn{2}{|c|}{ Month } & \multicolumn{3}{|c|}{ August } & \multicolumn{3}{|c|}{ September } & \multicolumn{3}{|c|}{ October } \\
\hline \multicolumn{2}{|c|}{$\begin{array}{l}\text { River } \\
\text { Parameters }\end{array}$} & Beni & Barour & Chakpheri & Beni & Barour & Chakpheri & Beni & Barour & Chakpheri \\
\hline \multirow{6}{*}{$\begin{array}{l}\text { Water } \\
\text { quality }\end{array}$} & Temp $\left({ }^{\circ} \mathrm{C}\right)$ & 30 & 29 & 28.5 & 30.6 & 30.8 & 29.3 & 27 & 26.5 & 25.2 \\
\hline & pH & 7.4 & 7.3 & 7.2 & 7.2 & 7.5 & 7.5 & 7.5 & 7.7 & 7.6 \\
\hline & TDS (mg/l) & 290 & 283 & 275 & 261 & 245 & 259 & 328 & 314 & 319 \\
\hline & DO (mg/l) & 6.2 & 5.9 & 6.5 & 5.9 & 5.7 & 6.2 & 6 & 6.2 & 6.7 \\
\hline & $\begin{array}{c}\text { Free } \mathrm{CO}_{2} \\
(\mathrm{mg} / \mathrm{l})\end{array}$ & 1.3 & 2.1 & 0 & 1.7 & 2.4 & 1.0 & 1.6 & 1.4 & 0 \\
\hline & $\begin{array}{c}\text { Alkalinity } \\
\text { (mg/l) }\end{array}$ & 120 & 112 & 105 & 128 & 125 & 118 & 148 & 135 & 128 \\
\hline \multirow{4}{*}{$\begin{array}{c}\text { Soil } \\
\text { quality of } \\
\text { catchment } \\
\text { area }\end{array}$} & pH & 7.2 & 7.3 & 7.0 & 7.4 & 7.6 & 7.2 & 7.5 & 7.8 & 7.5 \\
\hline & $\begin{array}{c}\text { Organic } \\
\text { Carbon (\%) }\end{array}$ & 0.8 & 1.1 & 1.8 & 0.9 & 1.0 & 1.3 & 0.6 & 0.8 & 1.4 \\
\hline & $\begin{array}{c}\text { Available } \\
\text { Nitrogen } \\
\text { (kg/ha) }\end{array}$ & 150.5 & 213.2 & 233.3 & 137.9 & 200.7 & 263.4 & 125.4 & 225.8 & 288.5 \\
\hline & $\begin{array}{c}\text { Available } \\
\text { Phosphorus } \\
\text { (kg/ha) }\end{array}$ & 23.4 & 29.3 & 32.4 & 26.3 & 26.9 & 30.1 & 25.1 & 30.6 & 33.9 \\
\hline
\end{tabular}


Fig.1Mean variation in water temperature $\left({ }^{\circ} \mathrm{C}\right)$ during the study period

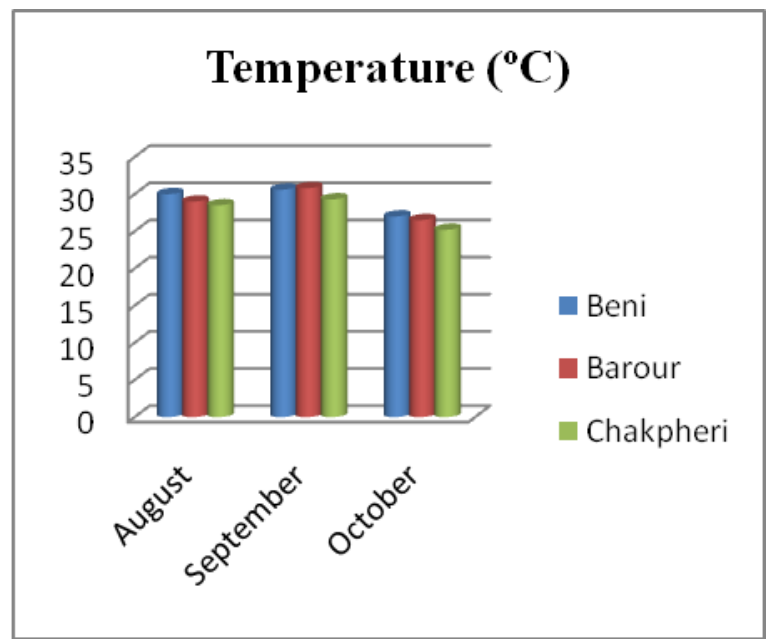

Fig.3 Mean variation in TDS (mg/l) during the study period

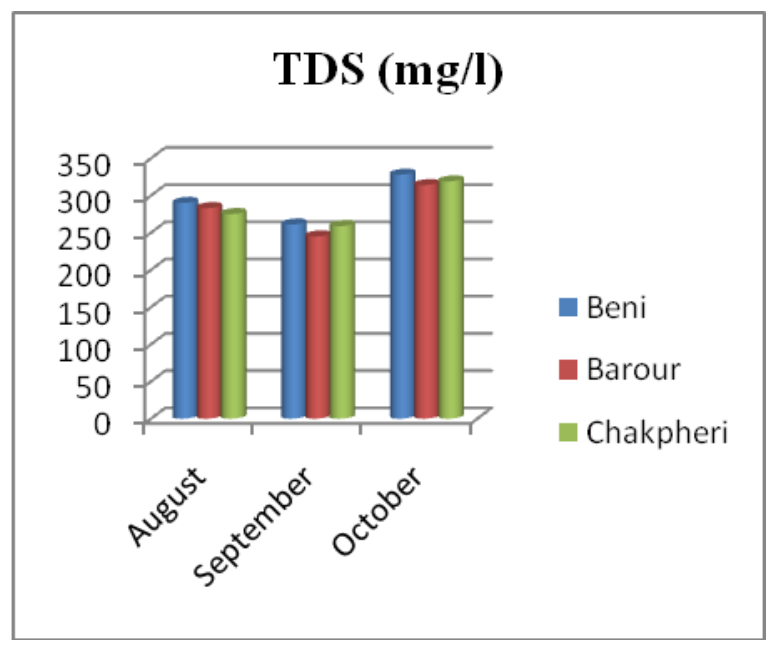

Fig.2 Mean variation in water $\mathrm{pH}$ during the study period

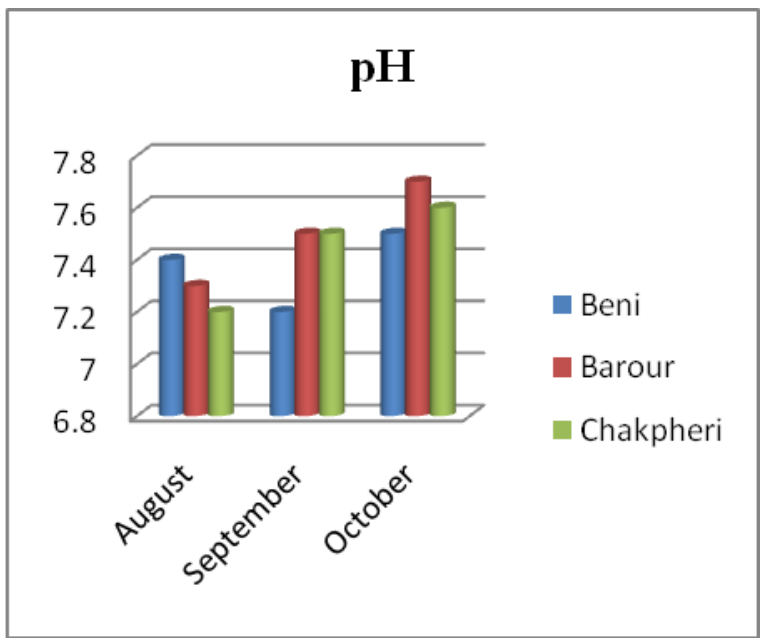

Fig.4 Mean variation in DO $(\mathrm{mg} / \mathrm{l})$ during the study period

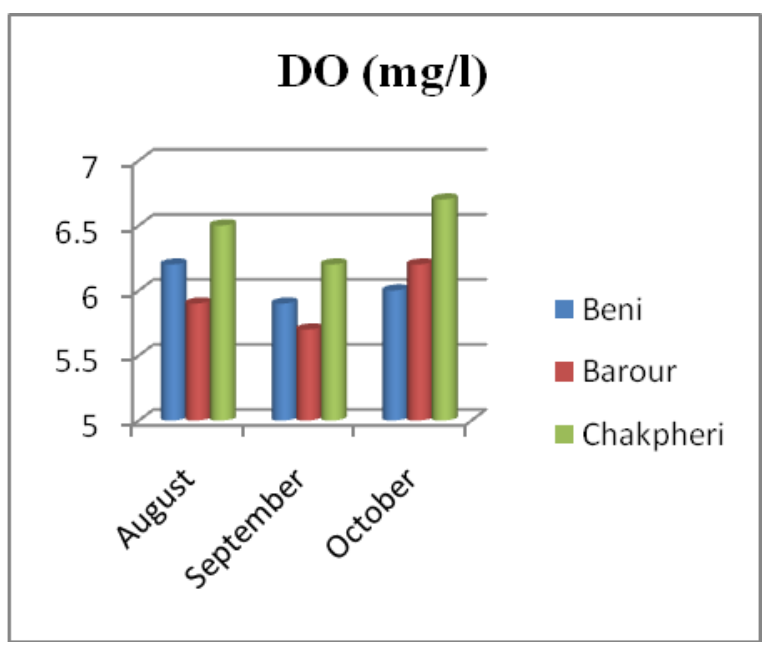


Fig.5 Mean variation in free $\mathrm{CO}_{2}(\mathrm{mg} / \mathrm{l})$ during the study period

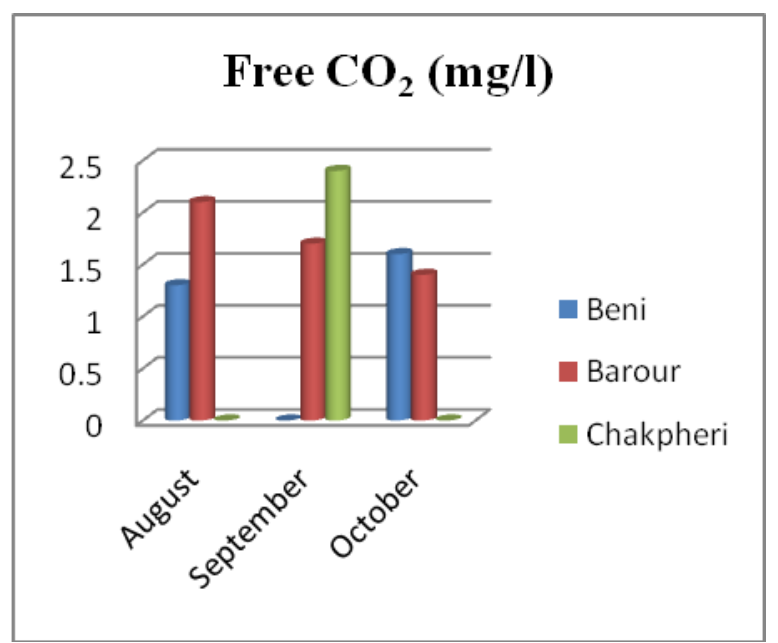

Fig.7 Mean variation in soil $\mathrm{pH}$ during the study period

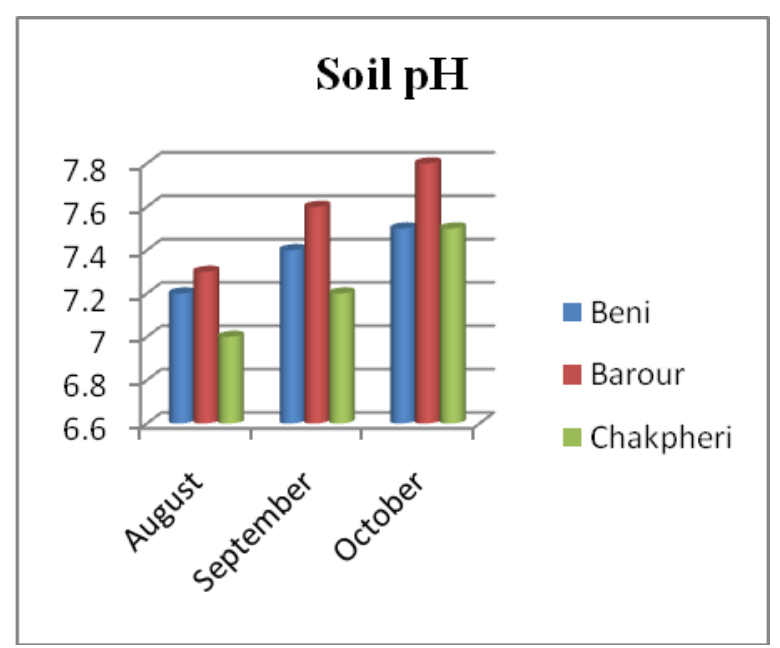

Fig.6 Mean variation in free alkalinity (mg/l) during the study period

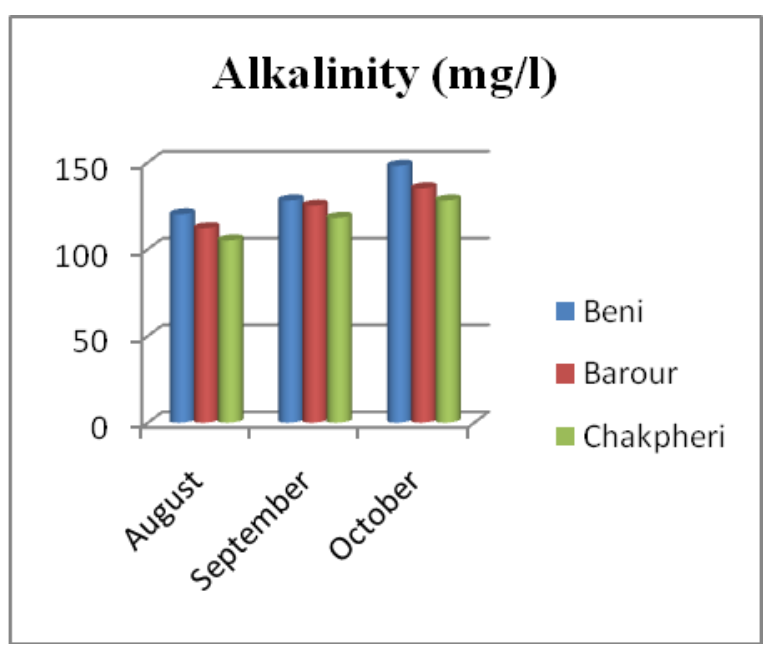

Fig.8 Mean variation in organic carbon (\%) during the study period

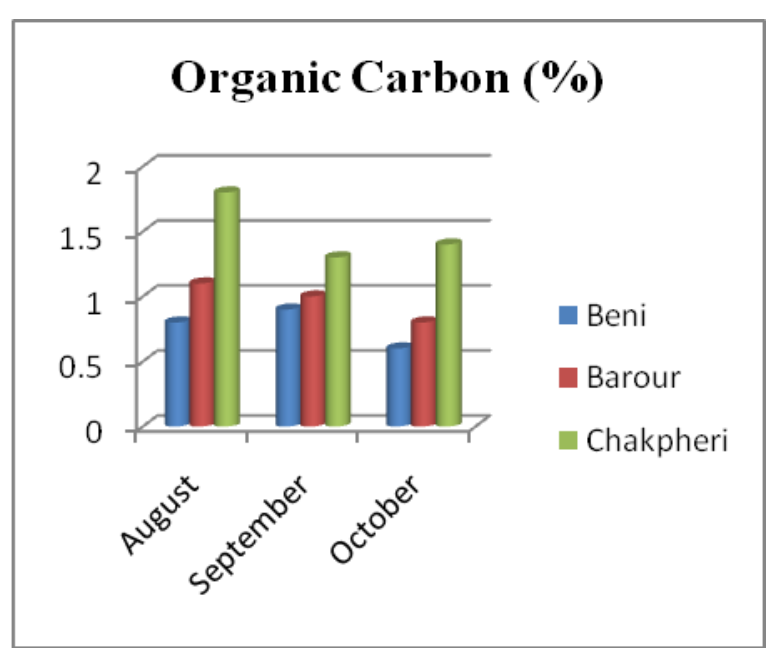


Fig.9 Mean variation in available nitrogen ( $\mathrm{kg} / \mathrm{ha}$ ) during the study period

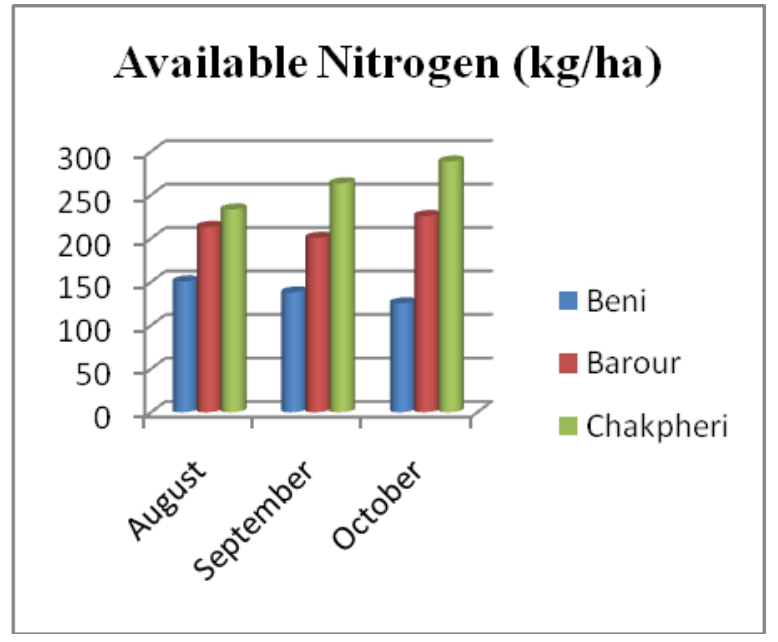

Out of the catchment area of the three rivers maximum phosphorus content is present in Chakpheri river and minimum in Beni river and the range varies from $23.4-33.9 \mathrm{~kg} / \mathrm{ha}$, as indicated in Figure 10.

In the given experiment we observed the impact of cropping pattern of catchment area on water quality conditions. It was observed that during the experiment in site $\mathrm{S}_{1}$ at Beni river Paddy (Oryza sativa) is planted in catchment area, which utilizes most of the nutrients from soil, thus soil at this site is deficient in organic compounds. Also the stagnant conditions of water at Beni river make it more warm and less saturated with water. Site $S_{2}$ is located at Barour river which contain Dhaincha (Sesbania bispinosa) at its catchment area, just like other legumes, it can be planted to improve the soil nutrients via nitrogen fixation. Thus soil of this site contains more organic material. Water of this site possesses less TDS and moderate DO, which shows good hydrobiological conditions of waterbody. Site $\mathrm{S}_{3}$ at Chakpheri river is maximum productive both in terms of soil quality and water quality characteristics. During August, catchment area around
Fig.10 Mean variation in available phosphorus $(\mathrm{kg} / \mathrm{ha})$ during the study period

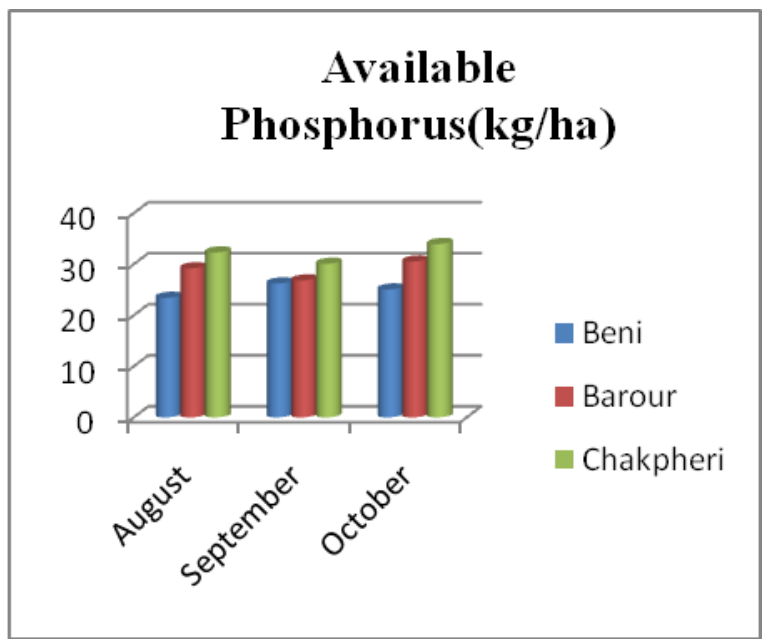

Chakpheri river is barren, so it becomes rich in nutrient but after a month maize (Zea mays) was planted in it, which also increases the productivity of soil. Also, the turbulent flowing condition of water makes this water saturated with oxygen which makes it productive. To manage our water quality parameters we should perform integrated management along with agriculture sector also, which plays a large determining role in contributing its physical and chemical characteristics.

\section{References}

Abler, D., Shortle, J., Carmichael, J., Horan, R. 2002. Climate change, agriculture, and water quality in the Chesapeake bay region. Clim. Chang. 55: 339-359.

Agarwal, N. K. and Thapliyal, B. L. 2005. Preimpoundment hydrological study of Bhilangana River from Tehri Dam reservoir area in Uttaranchal. Enviromental Geochemistry. 8. 143148.

Anbumozhi, V., Radhakrishnan, J. and Yamaji, E., 2005. Impact of riparian buffer zones on water quality and 
associated management considerations. Ecological Engineering, 24(5), pp.517523.

APHA. 2012. Standard methods for the examination of water and wastewater, 22 edition American Public Health Association, Washington, DC, USA. pp. 1360.

Bera, A., Dutta, T. K., Patra, B. C. and Sar, U. K. 2014. Monthly variation of physicochemical parameters and zooplankton density in Kangsabati Reservoir, West Bengal, India. International Journal of Advanced Research, 2(12): 279-289.

Carpenter, S.R., N.F. Caraco, D.L. Correll, R.W. Howarth, A.N. Sharpley, and V.H. Smith. 1998. "Nonpoint Pollution of Surface Waters with Phosphorus and Nitrogen." Ecological Applications 8(3):559-68.

Fomenky, N. N., Tening, A. S., Chuyong, G. B., Mbene, K., Asongwe, G. A., and Che, V. B. 2018. Selected physicochemical properties and quality of soils around some rivers of Cameroon. Journal of Soil Science and Environmental Management, 9(5), 6880.

Gao, T., Gao, M., Peng, J., and Li, N. 2018. Effects of Different Amount of Biochar on Nitrogen, Phosphorus and Potassium Nutrients in Soil. In IOP Conference Series: Materials Science and Engineering. 394(2): 22-43.

Gyawali, S., Techato, K., Yuangyai, C. ve Musikavong, C. 2013. Assessment of relationship between land uses of riparian zone and water quality of river for sustainable development of river basin, A case study of U-Taoao river basin, Thailand, Procedia Environmental Sciences. Pp. 291-297.

Havlin, J.L., Tisdale, S.L., Beaton, J.D. and Nelson, W.L. 2005. Phosphorus. In Soil fertility and fertilisers: An introduction to nutrient management. 7th Edition, Prentice Hall, Inc., New Delhi, India: pp 160-198.

Jadhav, S.D., Jadhav, M.S. and Jawale, R.W. 2013. Physico-Chemical and Bacteriological analysis of Indrayani River Water at Alandi, Pune District (Maharashtra) India. International Journal of Scientific and Engineering Research. 4 (11): 1941-1948.

Khatoon, N., Masihur, R., and Husain, K. A. 2013. Study of seasonal variation in the water quality among different ghats of river Ganga, Kanpur, India. Journal of Environmental Research and Development. 8(1): 1.

Koralage, I. S. A., Silva, N. R. N., and De Silva, C. S. 2015.. The determination of available phosphorus in soil: A quick and simple method.

Krantz, D. and Kifferstein, B. (2005). Water Pollution and Society. Journal of Environmental Law Practice, 4(1).

Kulkarni, S. J. 2016. Review on Research and Studies on Dissolved Oxygen and Its Affecting Parameters. International Journal of Research and Review. 3(8): 18-22.

Kutywawo, D., Chemura, A., and Chagwesha, T. 2012. Soil quality and cropping patterns as affected by irrigation water quality in mutema irrigation. In 13th WaterNet/WARFSA/GWP-SA

International Symposium on Integrated Water Resource Management (IWRM).

Liu, Z.J., D.E. Weller, D.L. Correll, and T.E. Jordan. 2000. Effects of Land Cover and Geology on Stream Chemistry in Watersheds of Chesapeake Bay. Journal of the American Water Resources Association. 36:1349-65.

Mello, K. D., Randhir, T. O.,Valente, R, A. and Vettorazzi, C.A., 2017. Riparian restoration for protecting water quality in tropical agricultural watersheds. Ecological Engineering, 1-11.

Narsimha, A., Narshimha, C. H., Srinivasulu, 
P., and Sudarshan, V. 2013. Relating apparent electrical conductivity and $\mathrm{pH}$ to soil and water in Kanagal surrounding area, Nalgonda district, Andhra Pradesh. Der Chemica Sinica, 4(2): 25-31.

Nimgare, S. S., Patankar, A. S., Telkhade, P. M., and Zade, S. B. 2014. Seasonal temperature changes and their influence on free carbon dioxide, dissolved oxygen (DO) and $\mathrm{pH}$ in Ashti Lake of Wardha district, Maharashtra. 2(2): 393-399.

Salahuddin, K., Visavadia, M., Gor, S., Gosai, C., Soni, V. K., and Hussain, M. D. 2014. Diel variations in limnological characteristics of Omkareshwar reservoir of Narmada River, India. Journal of Ecology and the Natural Environment. 6(1): 12-24.

Santhosh, B. and Singh, N.P. 2007. Guidelines for water quality management for fish culture in Tripura, ICAR Research Complex for NEH Region, Tripura Center, Publication no. 29.
Solanki, H. A., and Chavda, N. H. 2012. Physico-Chemical Analysis With Reference To Seasonal Changes In Soils Of Victoria Park Reserve Forest, Bhavnagar (Gujarat) By Ha Solanki And $\mathrm{Nh}$ Chavda. Life sciences Leaflets, 30, 62-to.

Stonestrom, D. A., Scanlon, B. R., and Zhang, L. 2009. Introduction to special section on Impacts of Land Use Change on Water Resources, Water Resour. Res., 45, W00A00.

Thirupathaiah, M., Samatha, C. H., and Sammaiah, C. 2012. Analysis of water quality using physico-chemical parameters in lower Manair reservoir of Karimnagar district, Andhra Pradesh. International Journal of Environmental Sciences, 3(1): 172.

Wolska, L. and Polkowska, Ż. 2001. Bacterial luminescence test screening of highly polluted areas in the Odra River. B. Environ. Contam. Tox., 67: 51.

\section{How to cite this article:}

Kusumlata Goswami, Mahima Tamta, Sumit Kumar and Ram, R.N. 2019. Impact of Cropping Pattern of Catchment Area on Water Quality Characteristics of Riverine Ecosystem. Int.J.Curr.Microbiol.App.Sci. 8(10): 420-429. doi: https://doi.org/10.20546/ijcmas.2019.810.044 